\title{
Presenteeism and safety culture: evaluation of health workers in a teaching hospital
}

\author{
Presenteísmo e cultura de segurança: avaliação dos trabalhadores de saúde de um hospital universitário \\ Presentismo y cultura de seguridad: evaluación de los trabajadores de la salud en un hospital universitario
}

\section{Roosi Eloiza Bolzan Zanon'
ORCID: 0000-0002-4033-5361 \\ Graziele de Lima Dalmolin' \\ ORCID: 0000-0003-0985-5788 \\ Tânia Solange Bosi de Souza Magnago' ORCID: 0000-0002-5308-1604 \\ Rafaela Andolhe' \\ ORCID: 0000-0003-3000-8188 \\ Rhanna Emanuela Fontenele Lima de Carvalho" ORCID: 0000-0002-3406-9685}

'Universidade Federal de Santa Maria. Santa Maria, Rio Grande do Sul, Brazil.

"Universidade Estadual do Ceará. Fortaleza, Ceará, Brazil.

How to cite this article: Zanon REB, Dalmolin GL, Magnago TSBS, Andolhe R, Carvalho REFL. Presenteeism and safety culture: evaluation of health workers in a teaching hospital. Rev Bras Enferm. 2021;74(1):e20190463. doi: http://dx.doi.org/10.1590/0034-7167-2019-0463

Corresponding author:

Roosi Eloiza Bolzan Zanon E-mail:roosi.zanon@gmail.com

EDITOR IN CHIEF: Dulce Barbosa ASSOCIATE EDITOR: Alexandre Balsanelli

Submission: 11-30-2019 Approval: 08-07-2020

\begin{abstract}
Objectives: to verify associations between presenteeism and safety culture among health workers. Methods: a descriptive, cross-sectional study with health workers from a teaching hospital in Rio Grande do Sul. Data collection took place through instruments of sample characterization, the Brazilian version of the Stanford Presenteeism Scale and the Safety Attitudes Questionnaire were analyzed using descriptive statistics and chi-square tests. Results: a total of 758 (48\%) professionals participated; 330 (43.5\%) presenteeism were identified, who evaluated the safety culture more negatively compared to non-presenteeism. The safety culture had a mean less than 75 ; associations between presenteeism and general safety culture were observed, and with the domains of teamwork climate, safety climate, stress recognition and working conditions. Conclusions: presenteeism was associated with a safety culture, which requires investment by hospital management, with consideration to the health of workers.

Descriptors: Presenteeism, Health Personnel, Occupational Health, Organizational Culture, Patient Safety.
\end{abstract}

\section{RESUMO}

Objetivos: verificar associações entre presenteísmo e cultura de segurança entre trabalhadores de saúde. Métodos: estudo descritivo, transversal, com trabalhadores de saúde de um hospital universitário do Rio Grande do Sul. Os dados coletados por meio de instrumentos de caracterização da amostra, a versão brasileira da Stanford Presenteeism Scale e o Questionário de Atitudes de Segurança, foram analisados por estatística descritiva e teste do quiquadrado. Resultados: participaram 758 (48\%) profissionais; identificaram-se $330(43,5 \%)$ presenteístas, os quais avaliaram a cultura de segurança mais negativamente comparados aos não presenteístas. A cultura de segurança obteve média inferior a 75; observaram-se associações entre presenteísmo e cultura de segurança geral, e com os domínios clima de trabalho em equipe, clima de segurança, reconhecimento do estresse e condições de trabalho. Conclusões: o presenteísmo esteve associado à cultura de segurança, a qual necessita de investimento por parte da gerência hospitalar, com atenção à saúde dos trabalhadores. Descritores: Presenteísmo, Pessoal de Saúde, Saúde do Trabalhador, Cultura Organizacional, Segurança do Paciente.

\section{RESUMEN}

Objetivos: verificar asociaciones entre el presentismo y la cultura de seguridad entre trabajadores de la salud. Métodos: estudio descriptivo, transversal con trabajadores de la salud de un hospital universitario de Rio Grande do Sul. Se analizaron los datos recolectados mediante instrumentos para la caracterización de la muestra, la versión brasileña de la Escala de Presentismo Stanford-6 y el Cuestionario de Actitudes de Seguridad, mediante la estadística descriptiva y la prueba de chi-cuadrado. Resultados: participaron 758 (48\%) profesionales; se identificó el presentismo en $330(43,5 \%)$, quienes evaluaron la cultura de seguridad de manera más negativa en comparación con los no presentistas. La cultura de seguridad promedió menos de 75 y hubo asociaciones entre el presentismo y la cultura de seguridad general, y con los dominios de trabajo en equipo, el clima de seguridad, percepción del estrés y las condiciones de trabajo. Conclusiones: el presentismo se asoció a la cultura de seguridad, que requiere inversión por parte de la dirección hospitalaria, con atención a la salud de los trabajadores.

Descriptores: Presentismo, Personal de Salud, Salud Laboral, Cultura Organizacional, Seguridad del Paciente. 


\section{INTRODUCTION}

The environments and relationships at work have a recognized influence on the workers' health/illness process. Considering the hospital, its purpose and the complexity symbolized by this institution, added to the effects of social and economic policies that affect everyone, there is a scenario of characteristics associated with the illness of its workers ${ }^{(1-3)}$.

It is not uncommon for workers to show up at work with signs or symptoms of illness, a condition called presenteeism, a current phenomenon in many workplaces, which can have serious consequences for organizations $s^{(4)}$. The evaluation of the costs of presenteeism is complex, since the worker is present in the workplace with the potential to spread diseases and compromise not only theirs, but overall productivity. Therefore, the worker is pointed out as responsible for losses greater than absenteeism, a condition in which the worker does not show up to work due to illness or other reasons, and is investigated to highlight its causes and, mainly, its repercussions on productivity, through a variety of scales ${ }^{(4-5)}$.

Considered for many reasons, presenteeism is not only related to health, but also the commitment evidenced by the degree of satisfaction and motivation with the work ${ }^{(5-6)}$. It varies according to sex, management support and encouragement to treat health problems, among other individual and organizational factors, such as fear of unemployment, for example. It is common among health and education workers, and in these areas, the fear of overloading colleagues and spoiling their work if they do not show up, are among the most prevalent reasons for presenteeism ${ }^{(4,6)}$. The phenomenon is worrying when it comes to hospital institutions, because the impact on productivity that results in patient care, can put you at risk and compromise their safety.

Patient safety emerges as a worldwide movement in health, a new paradigm that focuses on patients, in the face of evidence that they suffer damage resulting from failures in health services ${ }^{(7-8)}$. The World Health Organization (WHO) has founded an international alliance to address this issue, calling on countries to devote attention, coordinate, publicize and accelerate improvements on this subject, establishing safer health care ${ }^{(7)}$.

In Brazil, this movement is consolidated in the launching of specific legislation in 2013, establishing the National Patient Safety Program (PNSP) and the creation of the Patient Safety Centers (NSPs), with the general objective of contributing to the qualification of care in health ${ }^{(9-10)}$. Both address the safety culture, defined as the product of values, attitudes, perceptions and skills of individuals and groups, determinants of behavior and safety commitment, where guilt and punishment are substituted by conducting failures as an opportunity for learning and improvement ${ }^{(10)}$.

A specific focus is the assessment of the safety climate, the quantifiable part of this culture, by the professionals' perception of safety attitudes in their workplace. The assessment of the management's behavior, the way the teams respond, the communication, the response of failures and the professionals' perceptions of safety, points out the needed improvements to reach positive levels in the safety culture ${ }^{(11)}$. Since professionals are subject to lapses and failures that are impossible to fully control, work systems and processes must be more secure, providing support to the worker ${ }^{(12-13)}$. The working conditions, activity and health status of the health professional can contribute to a higher frequency of incidents related to the provision of care in health services ${ }^{(13-15)}$. Worker's health and safety culture are essential in the result of the quality of care and patient safety. Some authors identify the two sides of the same coin as being the relationship that combines these two dimensions, and point out the difficulty of working on incident prevention without involving the systemic view of the organization and the work development ${ }^{\left({ }^{(13)}\right)}$. The worker is also a victim when an event reaches the patient and, in this sense, cultural changes are essential, safeguarding everyone.

Only two articles from Croatia were found that assessed the association of safety and presenteeism culture, one with nurses from a general hospital ${ }^{(16)}$ and the other with doctors and nurses from two hospitals ${ }^{(17)}$. Therefore, an association study of these two constructs between health professionals in the national scenario is justified.

\section{OBJECTIVES}

To verify associations between presenteeism and safety culture among health workers.

\section{METHODS}

\section{Ethical aspects}

Ethical and legal guidelines were met, the authorization was obtained from the institution and a positive opinion was obtained from the local Research Ethics Committee on December $19^{\text {th }}$, 2017. Under Resolution 466/2012 of the National Health Council/ MS, the research objectives, the criteria and the method of participation, the possible risks and benefits, and the guarantee of confidentiality were presented. Those who agreed to participate in the study signed the Informed Consent Form (ICF).

\section{Design, period, and study scenario}

A cross-sectional descriptive study, product from a master's dissertation ${ }^{(18)}$, was carried out from March to July 2018, at a teaching hospital in Rio Grande do Sul, Brazil. This is a public hospital, a regional referral in health, serves medium and high complexity and works in teaching, research, and extension. The investigated units were: surgery and post-anesthetic recovery unit, material and sterilization center; clinical, surgical, oncological, pediatric, psychosocial, gynecological and obstetric inpatient units; pediatric, neonatal, adult and coronary intensive care units; emergency room; diagnostic services; outpatient clinics and hemotherapy; pharmacy and administrative places where health professionals worked.

\section{Population, sample, inclusion, and exclusion criteria}

There were 1,579 health professionals in the hospital at the time and the sample size determination for finite population, with an error of 0.05 and $95 \%$ confidence, estimated the minimum of 310 participants in the sample. However, as many participants as 
possible were invited. This was a convenience sampling, with the inclusion of 758 (48\%) participants, according to the following criteria: being a health professional (social worker, biomedical, biologist, nurse, pharmacist, physiotherapist, speech therapist, doctor, nutritionist, psychologist, occupational therapist, nursing technician, nursing assistant; laboratory, radiology and pharmacy technician; health assistant), having a minimum working time of four weeks in the unit and a minimum workload of 20 hours per week, enough for the worker to be familiar with the culture of local security and able to evaluate it ${ }^{(19-20)}$. Those who were on any type of leave during the data collection period were excluded.

\section{Study protocol}

The research protocol comprised a self-applied questionnaire with sociodemographic and labor variables (age, sex, higher education, position, unit of activity, work regimen), the Brazilian version of the Stanford Presenteeism Scale (SPS-6) ${ }^{(5,21)}$ to assess presenteeism and the Safety Attitudes Questionnaire (SAQ) to assess the safety culture ${ }^{(19-20)}$.

Before data collection, a pre-test was conducted among the research group members to assess the general understanding and the completion time of the instrument brochure. Subsequently, the training of the data collection team was carried out, composed of five master's students from the Graduate Nursing Program, each directing a group composed of a scientific initiation scholarship student and a member of the research group. All received the Collector's Manual, project documents and authorizations, and materials necessary for the research. There were demonstrations of procedures, discussion, and adjustment of conduct.

The team showed up in the field, inviting health professionals to participate in the research; handing out the instrument to be filled out by the participant, clarifying doubts, collecting the signature on the ICF and picking up the completed instrument. Many professionals were not found in the collection period or refused to participate in the research. Some kept the instrument and the collection was scheduled with up to three collection attempts on different days.

Many professionals went to work with health problems and, even so, the great majority evaluated that their productivity was maintained.

The institutional security culture was less than ideal. Despite being satisfied with the work, sector and performance team, the professionals signaled that there should be greater contact and communication with management, improvements in working conditions and the general safety culture.

The SPS- 6 was filled out by those who declared to show up at work in the last 30 days with a health problem or with signs or symptoms of illness ${ }^{(5,21)}$. The most common approach to assessing presenteeism, the worker assesses the impairment of his/her physical, mental and interpersonal activities at work ${ }^{(21)}$. With six items assessed on a five-point Likert scale, it describes how health status affected or not affected work in two dimensions: 'completing work' (CW= items 2, 5 and 6) and 'avoided distraction' (AD = items 1, 3 and 4, reverse) $)^{(5)}$.

The SAQ was chosen to assess the safety culture for its psychometric properties (Cronbach's alpha 0.7 to 0.8 ), history of application in several international studies ${ }^{(19-20)}$, and ability to provide information about what influences the safety climate and what needs to be improved in the institution ${ }^{(20)}$. It comprises 41 items and six domains: Teamwork climate, Safety climate, Job satisfaction, Stress recognition, Perception of management (of the unit and the hospital) and Working conditions. Each item follows the five-point Likert scale, from strongly disagree to strongly agree, including a 'not applicable' option; items 2, 11 and 36 are reverse ${ }^{(19-20)}$.

\section{Analysis of results and statistics}

The data were double and independently entered in Microsoft Excel $^{\circ}$, version 7.0. After checking and correcting errors and inconsistencies, they were exported and analyzed using the PASW Statistic ${ }^{\circ}$ program (Predictive Analytics Software, from SPSS Inc., Chicago, USA), version 18.0 for Windows, using descriptive statistics: for qualitative variables, distribution of relative and absolute frequency; for quantitative variables, position and dispersion measures (mean and standard deviation - SD or median and interquartile range - IIQ), according to the normality of data, and the Kolmogorov-Smirnov test for verification. The IIQ was calculated from the difference between the $75^{\text {th }}$ and the $25^{\text {th }}$ percentile.

Some variables such as position and work unit were regrouped, the first according to professional performance and the second according to similarities in the work process. The SPS- 6 and SAQ analysis followed the recommendations of the authors and translators.

The SPS- 6 analysis is done separately for the two dimensions, by direct score and by the sum of the scale global score after adjusting the $A D$ reverse score ${ }^{(5)}$. The scores added range from 6 to 30 ; a score $\leq 18$ indicates a reduction in performance and $>18$ represents a greater ability to concentrate and perform work $^{(5,21)}$. High values in the SPS- 6 and the CW total score, and a lower value in the $A D$, indicate better worker status and less impact of presenteeism at work.

For the SAQ analysis, the option "does not apply" should be disregarded and questions 2, 11 and 36 have scores reversed before the analysis. The final score ranges from 0 to 100; a value $\geq 75$ indicates a positive perception for the safety culture, assessed by the total number of SAQ items and for each dimension, separately ${ }^{(19-20)}$.

In verifying the association between presenteeism and safety culture, a bivariate analysis was performed using the chi-square test, considering significant the associations with $p<0.05$.

\section{RESULTS}

A total of 758 (48\%) health professionals participated, whose characterization showed: age from 20 to 70 years, median 40 (IIQ= 15); the prevalence of females, 595 (78.5\%), and with graduate level, 439 (58\%); the working time in the institution was a median of 54 months (IIQ = 151). Other labor variables described in Table 1 show the profile of the study participants.

The presenteeism was self-declared by 330 (43.5\%) workers, with a mean score of 20.9 (SD 4.7) on the global score of the SPS-6, ranging from 7 to 30 . The $\mathrm{CW}$ dimension had a mean of 12.5 (SD 2.7). In AD, the mean was 9.6 (SD 3.5). The points varied from 3 to 15 in both dimensions. The dichotomization of the scale showed that $104(31.5 \%)$ indicated reduced productivity, corresponding to $13.7 \%$ of the total study participants $(\mathrm{N}=758)$. 
Table 1 - Description of the work profile of health professionals, $N=758$, Rio Grande do Sul, Brazil, 2018

\begin{tabular}{lc}
\hline Variables & $\mathbf{n}(\%)$ \\
\hline Position & \\
Nursing Technicians and Assistants & $319(42.1)$ \\
Nurses & $192(25.3)$ \\
Doctors & $120(15.8)$ \\
Higher-education multi-professionals * & $78(10.3)$ \\
Pharmacy / radiology / laboratory technicians & $49(6.5)$ \\
Employment contract ${ }^{\dagger}$ & \\
Consolidation of labor laws & $359(47.4)$ \\
Uniform Administrative Law & $347(45.8)$ \\
Academic Connection - Medical Residency & $48(6.3)$ \\
Work unit & \\
UCRPA and CME§ & $98(12.9)$ \\
Medical Units & $85(11.2)$ \\
Pediatric ICU and Neonatal ICU** & $78(10.3)$ \\
CTMO, CTCriaC, Radiotherapy and Chemotherapy ${ }^{\dagger \dagger}$ & $76(10)$ \\
Gynecology and Obstetrics & $66(8.7)$ \\
General Surgery Unit - Hospitalization & $55(7.3)$ \\
Diagnostic Services & $55(7.3)$ \\
Ambulatory and Hemotherapy & $55(7.3)$ \\
Pharmacy and Management & $50(6.6)$ \\
Adult ICU and Coronary Care Unit & $48(6.3)$ \\
Emergency Room & $43(5.6)$ \\
Pediatric Unit & $28(3.7)$ \\
Psychosocial Unit & $21(2.8)$ \\
Total & $758(100)$ \\
\hline
\end{tabular}

Note: *social worker, biomedical, biologist, pharmacist, physiotherapist, speech therapist, nutritionist, psychologist, occupational therapist; ${ }^{\dagger}$ lost data; §UCRPA - Post-Anesthetic Surgery and Recovery Unit, CME-Material and Sterilization Center; ${ }^{* *}$ ICU - Intensive Care Unit; ${ }^{++}$CTMO-Bone Marrow Transplant Center, CTCriaC - Center for the Treatment of Cancer Children.

The safety culture evaluation obtained a mean score of 65.7 (SD 13.3) in the total of items. The mean of the SAQ dimensions ranged from 49.9 to 83.4 ; medians from 50 to 90 (Table 2).

Table 3 details the analysis of the association between a negative/positive safety culture (depending on the average less than or greater than 75) and the presence/absence of presenteeism.

The associations among positive/negative safety culture and presence/absence of presenteeism were significant $(p<0.05)$ for the total SAQ, and the domains: Teamwork climate, Safety climate, Stress recognition and Working conditions.

Table 2 - Descriptive analysis of the Safety Attitudes Questionnaire and its dimensions, Rio Grande do Sul, Brazil, 2018

\begin{tabular}{lccc}
\hline SAQ* and Dimensions & $\mathbf{n}^{\dagger}(\%)$ & Mean (SD) & $\begin{array}{c}\text { Median } \\
(\text { IIQ })^{* * *}\end{array}$ \\
\hline Total SAQ (41 items) & $509(67.2)$ & $65.7(13.3)$ & $67.1(19.5)$ \\
Teamwork climate & $668(88.1)$ & $72.0(16.9)$ & $75.0(20.8)$ \\
Safety climate & $700(92.3)$ & $67.6(17.5)$ & $67.9(25.0)$ \\
Job satisfaction & $741(97.8)$ & $83.4(16.8)$ & $90.0(15.0)$ \\
Stress recognition & $652(86.0)$ & $71.8(24.3)$ & $75.0(34.4)$ \\
Perception of Management & & & \\
$\quad$ Unit & $690(91.0)$ & $60.6(20.0)$ & $62.5(29.2)$ \\
$\quad$ Hospital & $693(91.4)$ & $49.9(21.7)$ & $50.0(30.0)$ \\
Working conditions & $703(92.7)$ & $60.7(24.5)$ & $66.7(41.7)$ \\
\hline
\end{tabular}

Note: *Safety Attitudes Questionnaire; ${ }^{+}$after ignoring the items marked with the "Not Applicable" option; ${ }^{5}$ Standard Deviation; **Interquartile Range.
Table 3 - Bivariate analysis of safety culture with presenteeism, Rio Grande do Sul, Brazil, 2018

\begin{tabular}{|c|c|c|c|c|}
\hline \multirow[b]{2}{*}{ SAQ* and Dimensions } & \multicolumn{2}{|c|}{ Presenteeism } & \multirow[b]{2}{*}{$\mathbf{n}^{\dagger}(\%)$} & \multirow[b]{2}{*}{$p$} \\
\hline & $\begin{array}{c}\text { No } \\
\mathrm{n}(\%)\end{array}$ & $\begin{array}{c}\text { Yes } \\
\text { n (\%) }\end{array}$ & & \\
\hline \multicolumn{5}{|l|}{ Total SAQ - 41 items } \\
\hline $\begin{array}{l}<75^{\S} \\
\geq 75^{* *}\end{array}$ & $\begin{array}{r}190(51.5) \\
85(63.9)\end{array}$ & $\begin{array}{r}179(48.5) \\
48(36.1)\end{array}$ & $502(66.2)$ & 0.014 \\
\hline \multicolumn{5}{|l|}{ Teamwork climate } \\
\hline $\begin{array}{l}<75 \\
\geq 75\end{array}$ & $\begin{array}{l}159(48.9) \\
211(62.1)\end{array}$ & $\begin{array}{l}166(51.1) \\
129(37.9)\end{array}$ & $665(87.7)$ & 0.001 \\
\hline \multicolumn{5}{|l|}{ Safety climate } \\
\hline $\begin{array}{l}<75 \\
\geq 75\end{array}$ & $\begin{array}{l}223(52.3) \\
167(61.9)\end{array}$ & $\begin{array}{l}203(47.7) \\
103(38.1)\end{array}$ & $696(91.8)$ & 0.014 \\
\hline \multicolumn{5}{|l|}{ Job satisfaction } \\
\hline $\begin{array}{l}<75 \\
\geq 75\end{array}$ & $\begin{array}{r}84(51.9) \\
331(57.7)\end{array}$ & $\begin{array}{r}78(48.1) \\
243(42.3)\end{array}$ & $736(97.1)$ & 0.188 \\
\hline \multicolumn{5}{|l|}{ Stress recognition } \\
\hline $\begin{array}{l}<75 \\
\geq 75\end{array}$ & $\begin{array}{l}163(62.9) \\
196(50.4)\end{array}$ & $\begin{array}{r}96(37.1) \\
193(49.6)\end{array}$ & $648(85.5)$ & 0.002 \\
\hline \multicolumn{5}{|c|}{ Perception of Management } \\
\hline \multicolumn{5}{|c|}{ Unit } \\
\hline $\begin{array}{l}<75 \\
\geq 75\end{array}$ & $\begin{array}{l}273(56.9) \\
113(54.9)\end{array}$ & $\begin{array}{r}207(43.1) \\
93(45.1)\end{array}$ & $686(90.5)$ & 0.625 \\
\hline \multicolumn{5}{|l|}{ Hospital } \\
\hline $\begin{array}{l}<75 \\
\geq 75\end{array}$ & $\begin{array}{r}322(56.3) \\
66(56.9)\end{array}$ & $\begin{array}{r}250(43.7) \\
50(43.1)\end{array}$ & $688(90.8)$ & 0.905 \\
\hline \multicolumn{5}{|l|}{ Working conditions } \\
\hline $\begin{array}{l}<75 \\
>75\end{array}$ & $213(51.6)$ & $200(48.4)$ & & 0.007 \\
\hline$\geq 75$ & $177(55.8)$ & $109(44.2)$ & $699(92.2)$ & 0.001 \\
\hline
\end{tabular}

\section{DISCUSSION}

In the evaluation of health professionals at this teaching hospital, an association of presenteeism with the safety culture was found. The prevalence of presenteeism was $43.5 \%$ and the general safety culture had an average score of 65.7. The SPS- 6 and SAQ are used internationally to assess the respective constructs ${ }^{(5,19)}$, however, no studies that used these two instruments together to assess this association was found.

The prevalence of presenteeism was high, 330 (43.5\%) professionals came to work with some health problem. However, most assessed that they managed to meet productivity goals. The loss of productivity was a reality for $13.7 \%$, pointing to a risk to the quality of care, which must be managed. The impact of this situation on patient protection should be considered to support improvements in quality and safety culture. Our finding is lower than that found in the SPS- 6 validation study in Brazil, which was $56.2 \%$, with only nursing staff ${ }^{(21)}$. In another study with New Zealand doctors and dentists, the prevalence of presenteeism was $88 \%{ }^{(22)}$.

Although presenteeism is repeated in health services, working, and being contaminated with infectious diseases can result in major problems, given the possibility of outbreaks in the workplace. In a context of an emerging health crisis, involving high-spread disease and serious cases, such as the current Covid-19 pandemic, presenteeism takes a special focus given the urgency of measures to control it. The recommendations of the WHO and the Ministry of Health advise that health service workers who present Flu Syndrome or Severe Acute Respiratory Syndrome, or who have 
close home contacts in these conditions, are immediately released from work and meet specific criteria for clinical or laboratory control to return to work activities. Respiratory infections prevention and control demand educational measures, not only to the observation of the main signs and symptoms, but also for health professionals to adhere to precautions and recommendations.

In the face of a pandemic, health professionals confront great risks, difficulties, and overload and it is essential to support health care measures for these workers. Numerous factors have been identified as important in the decision to follow regulations to control respiratory infections in health services, including the recommendation itself and the way it is communicated. Still: the support of managers, the culture of the workplace, training, physical space, access and confidence in personal protective equipment, the desire to provide good patient care, and the participation of all workers and units of the institution interfere in the effectiveness of preventive measures ${ }^{(23)}$. Awareness of these factors is an important way to prevent the spread of diseases by health professionals, which must be well described and communicated in all health services for patients and workers' safety.

The safety culture averaged less than 75 points, in agreement with national ${ }^{(24-25)}$ and international ${ }^{(19)}$ studies. Studies with SAQ in different regions of Brazil show similar results. In a hospital institution in Ceará, with characteristics similar to the hospital in this study ${ }^{(24)}$, the means were very close to the total SAQ (65 in that and 65.7 in this). A teaching hospital in Minas Gerais had averages in the total SAQ and dimensions below 70, except Job satisfaction, and the Perception of management obtained the lowest average ${ }^{(26)}$. In the Federal District, surgical center professionals pointed to even lower averages, except for Stress recognition, and no domain greater than $75^{(25)}$. In a nursing sample from two hospitals in the state of Rio Grande do Sul, the safety culture was assessed with higher averages and a positive score for Teamwork climate (76), Job satisfaction (88) and Working conditions (80) (27). The safety culture has a lot to enhance to provide greater protection for patients.

The low averages for the Perception of management stand out, corroborated in the studies above mentioned ${ }^{(20,24,27)}$. This domain assesses the support and performance of management, and its communication the team's in the safety culture, and generally has the lowest averages in the SAQ, especially regarding hospital management. On the other hand, Job Satisfaction, the only domain positively evaluated in this study, is also presented in others with the highest average ${ }^{(24)}$. This domain can be a support to improve the safety culture, as a satisfied worker can self-dedicate to improve patient care and attention, in alignment with management actions. An alignment between management and staff must bring together the desire of top management and what the staff expects from the institution, and not overlap, but a joint path towards the safety culture ${ }^{(12)}$.

In the analysis of the associations between the two constructs, it was observed, descriptively, that most of the presenteeists evaluated the safety climate with averages lower than 75, except for the dimensions Job satisfaction and Stress recognition, indicating that the professionals liked their work and recognized stressors, even under unfavorable health conditions. The association with presenteeism was significant $(p<0.05)$ for the total
SAQ and dimensions, except for Job satisfaction and Perception of management, both in the unit and in the hospital. The presenteeists tended to assess the security climate more negatively than non- presenteeists.

The low perception of the safety culture in concerning managements is a piece of evidence observed in research with SAQ, not only locally, but nationally and internationally ${ }^{(19,24)}$. So it was also observed with the application of another instrument to evaluate this culture, the Hospital Survey On Patient Safety Culture (HSOPSC), in a comparative study between Brazilian and Portuguese nurses, where the "Management support for patient safety" was the dimension with the greatest significant difference, and the most worrying in the professionals' perception ${ }^{(28)}$.

It seemed that the management of this teaching hospital did not actively play a role in the dissemination of the safety culture or, if it did, the worker was not aware of it, indicating a disparity on this path. Another possible explanation for this result is that the safety culture is a subject under construction and evolution in the institutions, and the management of hospitals is still strongly influenced by the biomedical model of health care, centered on the symbol of the doctor, and the safety culture is focused on the patient, aimed at controlling work processes and conditions, for safe multi-professional care. Another issue to be mentioned is the cut in health financing, with cutbacks that have repercussions on working conditions, credited to management deficiencies and inabilities, on the part of professionals. Any of these hypotheses are based on the distance between the two areas, with poor communication, and has a negative influence on the safety culture assessment.

On the other hand, the institution's professionals were satisfied with their job, which favored a safer climate. The dimension Job satisfaction, the only one that obtained a positive average (83.4) for safety culture, represents the positive view of the workplace: it evaluates the interest and pride in the work, the feeling of integration and the area/unit team's state of mind. The association of this satisfaction with the stability of the employment affiliation is considered a factor of dependability and quality of life at work ${ }^{(29)}$. As well as the importance and prestige of the hospital, a reference in the high complexity and $100 \%$ Unified Health System (SUS), essential to the right to health of more than one million people in the area covered.

The Teamwork Climate domain appears with an average of 72, closer to the positive, and credited to the increase in personnel that has occurred in the last five years in various professional categories and specialties. A new management model came to standardize the staff, exchanging previous hires with precarious bonds for professionals with public contracts, with greater stability. Standardizing bonds with health professionals is an important quality element in work and care ${ }^{(29)}$.

A study that evaluated presenteeism and safety culture among nurses in a hospital in Croatia using SPS- 6 and HSOPSC, respectively, found no association between the two constructs. All presenteeists scored above 18 on SPS-6, and the worst assessment on HSOPSC was about the 'non-punitive response to error $^{\prime(16)}$. Another Croatian study evaluated this association with medical and nursing workers from two hospitals and the lower performance at work was associated with a greater culture of 
patient safety ${ }^{(17)}$. The culture of patient safety was high, except for the dimensions of personal and non-punitive response to an error in both hospitals ${ }^{(16-17)}$, and hospital management support for patient safety in one of the hospitals ${ }^{(17)}$. Both studies showed that the punishment culture still stands out in institutions. This aspect has a direct relationship with the administrative conduct in risk management and evaluation of safety incidents, as it emphasizes the organizational culture in which the safety culture is inserted.

A large study involving 31 U.S. hospitals found an increase in safety culture scores in places where most of the team participated in rounds with the supervisor, the Leadership Walk Rounds, with even better results when the supervisors gave feedback to the teams. Also, they were significantly associated with better assessments of the safety culture, greater engagement of the workforce and less wear and tear, which was credited to a certain control over the quality of care that these conversations trigger to workers, reducing perceptions of burnout ${ }^{(30)}$. Such results emphasize the importance of approaching management to improve worker health and safety culture.

The SAQ result must be analyzed in the organization according to its concept, values and mission, as a managerial tool for decision-making in the planning and development of more positive environments for quality patient care. Although below expectations, considering the multiple actions of the NSP in investing patient safety in this hospital, the safety climate showed a small increase in the average over four years, showing that cultural changes demand time and continuous work in this direction.

Given the small number of studies that directly investigated the association of the two themes, greater comparisons were not possible. These results will assist in future discussions, since research that evaluated the interface between worker health and patient safety ${ }^{(13-15,30)}$ confirms the relevance of this and other studies. It is recommended to intensify the investigation, especially at the units/ sectors level, among the teams of specific units, to better understand the changeability of these results within the organization, since there can be great variation in the security climate between two sectors within the same hospital ${ }^{(19)}$. What makes space or team have a better security climate than another? It is possible to bring in best practices and stimulate this better climate in the institution.

\section{Limitations of the study}

The low participation by the multi-professional category, except for nursing, was a limitation of the study. There were difficulties in accessing and adherence by medical professionals, especially from open units. Low medical adherence was found in an assessment of the safety culture in other hospitals ${ }^{(24)}$.

The lost productivity must be better understood and adjusted to health care, with a definition of what a low performance means, both quantitatively and qualitatively, considering that in a hospital, the professionals of a team help each other in the performance of care.

\section{Contributions to the Health area}

This study allowed to intensify the understanding of the association of the constructs presenteeism and safety culture. The focus on the interface between worker health and patient safety guides improvements for the organization, by granting a close look at the professional. This implies, by personal opinion and group climate, how one feels at work and sees the institution concerning patient safety. It is a diagnosis that contributes to people and risk management, enabling to plan improvements for quality of life at work and quality of care, aiming at the safety of everyone.

\section{CONCLUSIONS}

The study found significant associations between presenteeism and general safety culture, and the following SAQ domains: Teamwork climate, Safety climate, Stress recognition and Working conditions. Those who worked with compromised health rated the general safety culture more negatively in this teaching hospital.

Many professionals went to work with health problems and, even so, the majority evaluated that their productivity was preserved.

The institutional safety culture was less than the ideal. Despite being satisfied with the work, unit and team, the professionals pointed out that there should be greater contact and communication with management, improvements in working conditions and the general safety culture.

\section{REFERENCES}

1. Antunes R, Praun L. A sociedade dos adoecimentos no trabalho. Serv Soc Soc. 2015;123:407-27. doi: 10.1590/0101-6628.030

2. Dejours C, Barros J, Lancman S. A centralidade do trabalho para a construção da saúde. Rev Ter Ocup. 2016;27(2):228-35. doi:10.11606/ issn.2238-6149.v27i2p228-235

3. Rosado IVM, Russo GHA, Maia EMC. Produzir saúde suscita adoecimento? as contradições do trabalho em hospitais públicos de urgência e emergência. Ciênc Saúde Coletiva. 2015;20(10):3021-32. doi: 10.1590/1413-812320152010.13202014

4. Johns G. Presenteeism in the workplace: a review and research agenda. J Organiz Behav. 2010;31:519-42. doi: 10.1002/job.630

5. Koopman C, Pelletier KR, Murray JF, Sharda CE, Berger ML, Turpin RS, et al. Stanford Presenteeism Scale: health status and employee productivity. J Occup Environ Med. 2002;44(1):14-20. doi: 10.1097/00043764-200201000-00004

6. Miraglia M, Johns G. Going to Work III: A Meta-Analysis of the Correlates of Presenteeism and a Dual-Path Model. J Occup Health Psychol [Internet]. 2016[cited 2018 Nov 07];21(3):261-83. Available from: https://core.ac.uk/download/pdf/146488667.pdf

7. Ministério da Saúde (BR). Fundação Oswaldo Cruz; Agência Nacional de Vigilância Sanitária Documento de referência para o Programa Nacional de Segurança do Paciente[Internet]. Brasília: Ministério da Saúde. 2014 [cited 2016 Aug 27]. 40 p. Available from: http://bvsms. saude.gov.br/bvs/publicacoes/documento_referencia_programa_nacional_seguranca.pdf 
8. Couto RC, Pedrosa TMG, Roberto BAD, Daibert PB, Abreu ACC, Leão ML. II Anuário da segurança assistencial hospitalar no Brasil - Propondo as Prioridades Nacionais [Internet]. Belo Horizonte: Faculdade de Medicina UFMG; 2018 [cited 2019 Jun 8]. 98 p. Available from: https:// www.iess.org.br/cms/rep/Anuario2018.pdf

9. Ministério da Saúde (BR). Portaria № 529, de $1^{\circ}$ de abril de 2013. Institui o Programa Nacional de Segurança do Paciente (PNSP) [Internet]. Diário Oficial da União, Brasília, DF, 02 abril. 2013 [cited 2019 Mar 22]. Available from: http://www.saude.mt.gov.br/upload/controleinfeccoes/pasta2/portaria-msgm-n-529-de-01-04-2013.pdf

10. Agência Nacional de Vigilância Sanitária (Anvisa). Resolução da Diretoria Colegiada - RDC n 36, de 25 de julho de 2013. Institui ações para a segurança do paciente em serviços de saúde e dá outras providências [Internet]. Diário Oficial da União, Brasília, DF, 26 jul. 2013 [cited 2019 Mar 22]. Available from: http://portal.anvisa.gov.br/documents/10181/2871504/RDC_36_2013_COMP. pdf/36d809a4-e5ed-4835-a375-3b3e93d74d5e

11. Colla JB, Bracken AC, Kinney LM, Weets WB. Measuring patient safety climate: a review of surveys. Qual Saf Health Care. 2005;14:364-366. doi: 10.1136/qshc.2005.014217

12. Amalberti R, Rocha R, Vilela RAG, Almeida IM. Safety management in complex and dangerous systems - theories and practices: an interview with René Amalberti. Rev Bras Saúde Ocup. 2018;43:e9. doi: 10.1590/2317-6369000021118

13. Sousa-Uva A, Serranheira F. Saúde do trabalhador, ergonomia e segurança do paciente. In: Sousa P, Mendes W. (Org.) Segurança do paciente: criando organizações de saúde seguras [Internet]. Rio de janeiro: EAD/ENSP. 2014 [cited 2108 Oct 10];p. 115-138. Available from: http://books.scielo.org/id/vtq2b/pdf/sousa-9788575415948.pdf

14. Aiken LH, Sermeus W, Van den Heede K, Sloane DM, Busse R, McKee M, et al. Patient safety, satisfaction, and quality of hospital care: crossectional surveys of nurses and patients in 12 countries in Europe and the United States. BMJ. 2012;344:e1717. doi: 10.1136/bmj.e1717

15. Vieira MLC, Oliveira EB, Oliveira NVD, Lisboa MTL, Progianti JM, Costa CCP. Nursing presenteeism: repercussions on workers' health and patient safety. Rev Enferm UERJ. 2018;26:e31107. doi: 10.12957/reuerj.2018.31107

16. Brborović $\mathrm{H}$, Brborović $\mathrm{O}$, Brumen V, Pavleković $\mathrm{G}$, Mustajbegović J. Are nurse presenteeism and patient safety culture associated: a crosssectional study. Arh Hig Rada Toksikol. 2014;65(2):149-56. doi: 10.2478/10004-1254-65-2014-2462

17. Brborović $\mathrm{H}$, Brborović O. Patient safety culture shapes presenteeism and absenteeism: a cross-sectional study among Croatian healthcare workers. Arh Hig Rada Toksikol. 2017;68(3):185-9. doi: 10.1515/aiht-2017-68-2957

18. Zanon REB. Presenteísmo e Cultura de Segurança no ambiente hospitalar [Dissertação]. Santa Maria: Programa de Pós-graduação em Enfermagem da Universidade Federal de Santa Maria; 2019.

19. Sexton JB, Helmreich RL, Neilands TB, Rowan K, Vella K, Boyden J, et al. The Safety Attitudes Questionnaire: psychometric properties, benchmarking data, and emerging research. BMC Health Serv Res. 2006;6:44. doi: 10.1186/1472-6963-6-44

20. Carvalho REFL, Cassiani SHB. Cross-cultural adaptation of the Safety Attitudes Questionnaire - Short Form 2006 for Brazil. Rev Latino-Am Enfermagem. 2012;20(3):575-82. doi: 10.1590/S0104-11692012000300020

21. Paschoalin HC, Griep RH, Lisboa MTL, Bandeira de Mello DC. Transcultural adaptation and validation of the Stanford Presenteeism Scale for the evaluation of presenteeism for Brazilian Portuguese. Rev. Latino-Am. Enfermagem. 2013;21(1):388-395. doi:10.1590/ S0104-11692013000100014

22. Chambers C, Frampton C, Barclay M. Presenteeism in the New Zealand senior medical workforce: a mixed methods analysis. N Z Med J [Internet]. 2017 [cited 2018 Nov 12];130(449):10-22. Available from: http://www.nzma.org.nz/_data/assets/pdf_file/0005/53069/ChambersFINAL.pdf

23. Houghton C, Meskell P, Delaney H, Smalle M, Glenton C, Booth A et al. Barriers and facilitators to healthcare workers' adherence with infection prevention and control (IPC) guidelines for respiratory infectious diseases: a rapid qualitative evidence synthesis. Cochrane Database of Syst Rev. 2020;4(4):doi: 10.1002/14651858.cd013582

24. Carvalho REFL, Arruda LP, Nascimento NKP, Sampaio RL, Cavalcante MLSN, Costa ACP. Assessment of the culture of safety in public hospitals in Brazil. Rev Latino-Am Enfermagem. 2017;25:e2849. doi: 10.1590/1518-8345.1600.2849

25. Carvalho PA, Göttems LBD, Pires MRGM, Oliveira MLC. Safety culture in the operating room of a public hospital in the perception of healthcare professionals. Rev Latino-Am Enfermagem. 2015;23(6):1041-8. doi: 10.1590/0104-1169.0669.2647

26. Luiz RB, Simões ALA, Barichello E, Barbosa MH. Factors associated with the patient safety climate at a teaching hospital. Rev Latino-Am Enfermagem. 2015;23(5):880-7. doi: 10.1590/0104-1169.0059.2627

27. Toso GL, Golle L, Magnago TSBS, Herr GEG, Loro MM, Aozane F, et al. Patient safety culture in hospitals within the nursing perspective. Rev Gaúcha Enferm. 2016;37(4):e58662. doi: 10.1590/1983-1447.2016.04.58662

28. Fassarella CS, Camerini FG, Henrique DM, Almeida LF, Figueiredo MCB. Evaluation of patient safety culture: comparative study in university hospitals. Rev Esc Enferm USP. 2018;52:e03379. doi: 10.1590/s1980-220x2017033803379

29. Alves SMP, Coelho MCR, Borges LH, Cruz CAM, Massaroni L, Maciel PMA. The flexibilization of employment relationships in the health sector: the reality in a Federal University Hospital in Brazil. Ciênc Saúde Colet. 2015;20(10):3043-50. doi: 10.1590/1413-812320152010.11592014

30. Sexton JB, Adair KC, Leonard MW, Frankel TC, Proulx J, Watson SR, et al. Providing feedback following Leadership Walk Rounds is associated with better patient safety culture, higher employee engagement and lower burnout. BMJ Qual Saf. 2018;27:261-70. doi: 10.1136/ bmjqs-2016-006399 